\title{
Burden and Trends of Severe Rotavirus Infections and All- cause Acute Gastroenteritis Hospital Episodes in Children Under Five Years Old in Mainland Portugal
}

\author{
Carga e Tendências dos Episódios Hospitalares de \\ Infeções Graves por Rotavírus e Gastroenterite Aguda \\ Grave em Crianças com Menos de Cinco Anos, em \\ Portugal Continental
}

\author{
Héloïse LUCACCIONI $\triangle^{1,2}$, Rita SÁ MACHADO ${ }^{1}$ \\ Acta Med Port 2021 Oct;34(10):669-676 - https://doi.org/10.20344/amp.15706
}

\section{ABSTRACT}

Introduction: Rotavirus infections are a leading cause of severe acute gastroenteritis in children under five years old. In December 2019, Portugal announced the inclusion of the rotavirus vaccine, already available for private purchase, in the National Immunization Program. We present the first nationwide analysis of the burden and trends of rotavirus and acute gastroenteritis hospital episodes in children under five years old in mainland Portugal (2014 - 2017).

Material and Methods: We used the hospital morbidity database and the Death Certificate Information System to identify hospital episodes and deaths of rotavirus and acute gastroenteritis based on the codes of the International Classification of Diseases. We described the number and rates of hospital episodes disaggregated by age group, sex, geographical units, and the seasonality and trends over the study period.

Results: On average, during the study period, there were 1985 annual hospital episodes among children under five years old. The annual rate was $48.0 / 10000$ children ( $95 \% \mathrm{Cl} 46.9$ - 49.0). Rates were consistently higher in younger children, and $67.8 \%$ episodes occurred in children under 24 months. We found a seasonal pattern with a major peak in the early spring.

Discussion: Our results were consistent with the current knowledge on rotavirus and acute gastroenteritis hospital episodes in Europe. Additional studies are needed to identify the risk factors and high-risk groups for hospital attendance.

Conclusion: Rotavirus and acute gastroenteritis hospital episodes in children under five years old in mainland Portugal represent an important health and economic burden. In the future, monitoring this burden and these trends in relation with rotavirus vaccine coverage could be useful in order to assess the impact of the vaccination programme on the change in hospital episodes.

Keywords: Child; Gastroenteritis; Hospitalization; Portugal; Rotavirus Infections; Rotavirus Vaccines

\section{RESUMO}

Introdução: As infeções por rotavírus são uma das principais causas de gastroenterite aguda grave em crianças com menos de cinco anos. Em dezembro de 2019, foi anunciada a inclusão da vacina contra rotavírus, já disponível no mercado privado, no Programa Nacional de Vacinação. Esta é a primeira análise nacional da carga e tendência dos episódios hospitalares de rotavírus e gastroenterite aguda grave em crianças com menos de cinco anos em Portugal continental (2014 - 2017).

Material e Métodos: Utilizou-se a base de dados de morbilidade hospitalar e o sistema de informação de certificados de óbito para identificar episódios hospitalares e mortes por rotavírus e gastroenterite aguda grave, a partir de códigos da classificação internacional de doenças. Descreveu-se o número e as taxas de episódios hospitalares, desagregadas por grupo etário, sexo, geografia, e a sazonalidade e tendências ao longo do período em estudo.

Resultados: Em média, houve 1985 episódios hospitalares anuais em crianças com menos de cinco anos. A taxa anual foi de 48,0/ 10000 crianças (95\% IC 46,9 - 49,0). A taxa de hospitalização foi consistentemente mais elevada em crianças mais jovens, e 67,8\% dos episódios ocorreram em crianças com menos de 24 meses. Relativamente à sazonalidade, encontrámos um pico no início da Primavera.

Discussão: Os resultados foram consistentes com os conhecimentos atuais sobre rotavírus e episódios hospitalares de gastroenterite aguda grave na Europa. São necessários estudos adicionais para identificar os fatores e grupos de risco de infeções graves.

Conclusão: Em Portugal Continental, os episódios hospitalares de rotavírus e gastroenterite aguda grave em crianças de idade inferior a cinco anos têm um impacto negativo relevante na saúde e na economia. No futuro, e na perspetiva da introdução da vacinação para o rotavírus, estes indicadores serão relevantes para monitorizar o impacto do programa de vacinação na diminuição dos episódios hospitalares.

Palavras-chave: Gastroenterite; Hospitalização; Infecções por Rotavirus; Portugal; Vacinas contra Rotavirus

\section{INTRODUCTION}

Rotavirus is a leading cause of severe acute gastroenteritis worldwide, specifically among children under five years old. Rotavirus infections are usually mild and deaths are rare in high-income countries. By the age of five, most children have been infected and developed some immunity, such that subsequent infections rarely cause severe

1. Division of Epidemiology and Statistics. Direção-Geral da Saúde. Lisboa. Portugal.

2. European Program for Intervention Epidemiology Training. European Centre for Disease Prevention and Control. Stockholm. Sweden.

$\square$ Autor correspondente: Héloïse Lucaccioni. heloiselucaccioni@dgs.min-saude.pt

Recebido: 12 de janeiro de 2021 - Aceite: 02 de março de 2021 - First published: 25 de março de 2021 - Online issue published: 01 de outubro de 2021 Copyright @ Ordem dos Médicos 2021 
disease. ${ }^{1}$ Yet, severe cases can lead to rapid dehydration requiring medical care, and in some cases, hospitalization.

In Europe, hospitalization rates vary around $30-60$ per 10000 children under 5 years old, while two to four times more children are estimated to seek medical care in outpatient settings. ${ }^{2}$ As such, rotavirus infections still represent a significant burden with high social and economic costs for the healthcare systems and the households (e.g., healthcare cost and resource utilization, workdays lost). ${ }^{3-5}$

Proper hand hygiene and sanitation are essential measures to prevent the faecal-oral transmission, but the high transmissivity and environmental persistence of rotavirus limit the impact of such measures. Therefore, vaccination plays an important role in reducing the disease burden. ${ }^{6}$ In 2009, the World Health Organization (WHO) recommended the inclusion of the rotavirus vaccine in the National Immunization Programs (NIP). ${ }^{7}$ To date, 107 countries worldwide, of which 18 European countries, have adopted that recommendation. 8,9 In Europe, two orally administered vaccines are available, both with evidence of a high preventive efficacy, a limited safety risk of intussusception, and a positive impact in reducing hospitalizations and medical attendance during the rotavirus season, as well as some evidence of herd immunity. ${ }^{10-14}$ According to Parez et al, ${ }^{15}$ the main barriers to rotavirus vaccination in Europe are the perception of a low disease burden, the lack of awareness around costeffectiveness, and further safety concerns.

In Portugal, the two vaccines are available for private purchase since 2006. According to the Portuguese Society of Paediatrics, the vaccine coverage has progressively increased and reached a moderate level of $45 \%$ in $2016 .{ }^{16}$ In 2009, the same institution formulated recommendations for the universal vaccination of children, ${ }^{16}$ and, in December 2019, Portugal announced the inclusion of the rotavirus vaccine in the national immunization program, for risk groups in need to be defined. ${ }^{17}$

In Portugal, few nationwide data exist on the burden and epidemiology of severe rotavirus infections and acute gastroenteritis (AGE) in children. In 2007, regional studies estimated the proportion of rotavirus infections among children with AGE in hospital short-stay units or emergency departments, with results ranging from $40.0 \%$ to $55.2 \% .^{18,19}$ A national multicentre observational study conducted in 2008 - 2009 found that around a third of children under five years old attending paediatric emergency departments with AGE were infected by rotavirus, with the highest proportion during spring and among children 7 - 24 months. ${ }^{20}$ In 2013, Rodrigues et $a^{21}$ further investigated the evolution of the proportion of rotavirus-associated AGE among children under five years old in emergency departments, over six surveillance seasons. The authors found fluctuating interannual proportions (from $25 \%$ to $49 \%$ ), with no clear trends or seasonal shift, and concluded that higher levels of vaccine coverage may be necessary to obtain significant impact on the rotavirus burden.

Although laboratory diagnosis is not routinely performed by clinicians, it is estimated that rotavirus infections repre- sent $30 \%-50 \%$ of AGE hospital episodes in children, such that rotavirus vaccination programmes are expected to lead to a visible reduction in AGE hospitalization. ${ }^{22,23}$

This study aims to examine national data on severe rotavirus infections and AGE hospital episodes in children under five years old in mainland Portugal between 2014 and 2017 , in order to describe the burden and trends before the introduction of the rotavirus vaccine in the NIP.

\section{MATERIAL AND METHODS}

We conducted a retrospective observational study using data on hospital morbidity and mortality surveillance coded for rotavirus and AGE diagnoses in children under five years old in mainland Portugal between 2014 and 2017.

\section{Hospital morbidity data}

Hospital morbidity data were obtained from the Hospital Morbidity Database (BDMH) published by the Central Administration of the Health System (ACSS, IP) on the $11^{\text {th }}$ November 2019. The database contains clinical and administrative information concerning all inpatient and outpatient hospital episodes within the National Health Service (NHS) in Portugal. A hospital episode designates the period of time between admission and discharge, during which a patient receives care. Each record of the database represents one clinical diagnosis from a single hospital episode from one patient.

Clinical diagnoses are coded in a systematic manner in accordance with the International Classification of Diseases, Clinical Modification (ICD-CM) $9^{\text {th }}$ edition (until 31 $1^{\text {st }}$ December 2016) or $10^{\text {th }}$ edition (from 2016 for pilot hospitals, and 2017 for all hospitals). We extracted any first to fourth diagnosis of rotavirus infections and all-cause AGE in children under five years old in mainland Portugal between 2014 and $2017 .{ }^{24}$ The ICD codes of interest included diarrhoea of undetermined aetiology presumed infectious (A09), diarrhoea of determined aetiology of bacterial (A00.0 - A05.9), parasitic (A06 - A07.9), and viral origin (A08.0 - A08), including rotavirus (A08.0). Diarrhoea of undetermined aetiology presumed non-infectious was excluded. ${ }^{25}$ Whenever needed, we used concordance tables to account for changes in different versions of the ICD-CM classification system (see Appendix 1: https://www.actamedicaportuguesa.com/revista/index.php/amp/article/view/15706/Appendix_01.pdf).

A single patient could appear multiple times in the database because several diagnoses of all-cause AGE could be recorded as any first to fourth diagnosis for the same hospital episode. Similarly, a single patient could have multiple consecutive admissions for all-cause AGE, at different dates. In case of multiple diagnoses of AGE related to the same hospital episode, we ensured that only one record was kept, avoiding double counting the episode. We kept the record of the rotavirus diagnosis where existent and independently of the diagnosis order, but otherwise we kept the record of the first $A G E$ diagnosis in order. Consecutive hospital admissions for all-cause AGE were considered distinct episodes if 14 days or more elapsed between the first 
discharge and the subsequent admission. ${ }^{25}$ If less than 14 days elapsed, they were considered a single hospital episode and only the relevant record of the earliest admission was kept. We used the unique identifier of hospital episodes and the unique identifier of patients to identify single hospital episodes with several diagnoses of all-cause AGE, and consecutive hospital episodes of the same patient. A very limited number of records $(n=104)$ did not have any unique patient identifier; therefore, we used date of birth, sex, and borough of residence as proxies to distinguish unique patients.

\section{Mortality data}

Mortality data were obtained from the Death Certificate Information System (SICO). We extracted deaths due to rotavirus and all-cause AGE in children under five years old in mainland Portugal for the period 2014 - 2017. Causes of deaths were identified based on the same list of ICD codes considered for the hospital episodes.

\section{Denominators for rates calculation}

We calculated rates of all-cause AGE hospital episodes in children under five (per 10 000), using the annual resident population of children under five in mainland Portugal, published by Statistics Portugal (Instituto Nacional de Estatística, INE), ${ }^{26}$ as the denominators. As such, we divided the number of hospital episodes with relevant ICD codes by the number of children under five for each given year (annual rate) or week (weekly rate), and we calculated the associated $95 \%$ Poisson confidence interval $(95 \% \mathrm{Cl})$.

Similarly, we calculated age and sex-specific rates using disaggregated data and denominators by age group or gender, for each given year.

Finally, to compare rates between geographical units (NUTS2), we calculated age and sex-adjusted rates applying a direct standardization method using the annual age and sex distribution of the resident population of children under five years old in mainland Portugal as a reference (see Appendix 2: https://www.actamedicaportuguesa.com/ revista/index.php/amp/article/view/15706/Appendix_02. pdf).

\section{Data analysis}

We conducted a descriptive analysis of the mortality, number, and annual rates of rotavirus and all-cause AGE hospital episodes by age group, sex, and geographical units (districts and NUTS2), as well as the duration of hospital episodes. We excluded 110 records (5.7\%) with missing information on NUTS2 from the calculation of rates by NUTS2, but they were included in other analyses.

Finally, we plotted and described the weekly number and the weekly rates of hospital episodes over the four-year study period to assess the seasonality and trends.

Data used in this study were secondary data available under public health surveillance and monitoring activities. They were anonymized prior to collection and analysis, thus preserving the confidentiality of individuals, and requiring no supplementary ethical clearance.

Data cleaning and analyses were performed in R Statistical Software v4.0.0.27

Table 1 - Number and proportion of all-cause acute gastroenteritis hospital episodes by diagnosis code sequence, age groups, sex, and geographical units, mainland Portugal (2014 - 2017)

\begin{tabular}{lcc}
\hline & $\mathbf{n}$ & $(\%)$ \\
\hline Episodes of all-cause AGE & 7936 & - \\
Rotavirus & 2540 & 32.0
\end{tabular}

Other AGE $\quad 5396 \quad 68.0$

\section{Diagnosis code sequence}

$\begin{array}{lcc}\text { Principal } & 6552 & 82.6 \\ \text { Secondary } & 856 & 10.8 \\ \text { Third } & 391 & 4.9 \\ \text { Fourth } & 137 & 1.7 \\ \text { Sex } & & \\ \text { Girl } & 3528 & 44.5 \\ \text { Boy } & 4408 & 55.5\end{array}$

Age groups (in months)

$\begin{array}{lll}<6 & 1458 & 18.4 \\ 6-11 & 1625 & 20.5 \\ 12-17 & 1297 & 16.3 \\ 18-23 & 998 & 12.6 \\ 24-29 & 707 & 8.9 \\ 30-35 & 500 & 6.3 \\ 36-41 & 418 & 5.3 \\ 42-47 & 339 & 4.3 \\ 48-53 & 298 & 3.8 \\ 54+ & 296 & 3.7\end{array}$

Geographical units (Districts)

\begin{tabular}{lcc} 
Lisbon & 1869 & 23.6 \\
Porto & 1543 & 19.4 \\
Braga & 819 & 10.3 \\
Aveiro & 539 & 6.8 \\
Setúbal & 493 & 6.2 \\
Santarém & 388 & 4.9 \\
Vila Real & 293 & 3.7 \\
Castelo Branco & 280 & 3.5 \\
Coimbra & 261 & 3.3 \\
Leiria & 244 & 3.1 \\
Faro & 223 & 2.8 \\
Bragança & 219 & 2.8 \\
Évora & 168 & 2.1 \\
Beja & 141 & 1.8 \\
Viana Do Castelo & 123 & 1.5 \\
Viseu & 104 & 1.3 \\
Guarda & 96 & 1.2 \\
Portalegre & 86 & 1.1 \\
Unknown & 47 & 0.6 \\
\hline AGE: all-cause acute gastroenteritis & &
\end{tabular}

AGE: all-cause acute gastroenteritis 


\section{RESULTS}

\section{Burden of rotavirus infections and all-cause AGE hos- pital episodes}

Table 1 presents the number and proportion of rotavirus and all-cause AGE hospital episodes by diagnosis code sequence, age group, sex, and geographical unit. Between 2014 and 2017, a total of 7936 all-cause AGE hospital episodes were recorded in children under five years old in mainland Portugal, for an annual average of 1984 episodes/year. Of these episodes, 2540 (32.0\%) were coded as rotavirus infections. The proportion of hospital episodes coded as rotavirus ranged from $20.6 \%$ to $27.0 \%$ during the four-year study period. All-cause AGE was the main diagnosis in $82.6 \%$ (6552) of these hospital episodes.

More than two thirds of the hospital episodes $(67.8 \%$, 5378 ) occurred in children under 24 months, of which $57.3 \%$ (3083) in the first year of life. The proportion of allcause AGE hospital episodes then decreased as age increased. AGE hospital episodes represented 15.2\% (1207) among those aged 24 - 35 months, 9.5\% (757) among children aged 36 - 47 months, 3.8\% (298) among the 48 - 53 months age group, and $3.7 \%$ (296) among those 54 months and older. Boys were slightly more represented than girls, with $55.5 \%$ (4408) of all AGE hospital episodes.

Overall, AGE hospital episodes represented a total of 29 224 days of hospital attendance during the four-year study period, which is an annual average of 7306 days/year. The mean duration of hospital episodes was 3.7 days (interquartile range: 2.0 - 4.0 days). Moreover, the median duration of hospital episodes was consistently higher in younger age groups, i.e., 3.0 days for children under 36 months versus 2.0 days for those aged 36 months and older. Finally, the duration of hospital episodes was longer for those with a rotavirus diagnosis compared to other AGE diagnoses (4.4 days versus 3.4 days, on average).

\section{Deaths from all-cause AGE}

During the four-year study period, two deaths due to allcause AGE, of which one was rotavirus, were reported in children of 15 months and 37 months, respectively.

\section{Rates of all-cause AGE hospital episodes}

During the four-year study period, the annual rate of all-cause AGE hospital episodes in children under five was 48.0 episodes per 10000 children/year (95\% Cl 46.9 - 49.1) (Table 2). In other words, 1 in 208 children was likely to have attended hospital for all-cause AGE by the age of five.

The annual rates varied between age groups from 17.0 (48 months and older) $(95 \% \mathrm{Cl} 15.6$ - 18.3) to 95.1 (under 12 months old) (95\% Cl 91.8 - 98.5) per 10000 , with a clear trend of decreasing rates as age increased. More specifically, rates were higher in the younger age groups (under 24 months old), but systematically below the overall estimate for all the subsequent older groups.

Furthermore, rates were consistently higher in boys, on average $52.0(95 \% \mathrm{Cl} 50.5$ - 53.5) vs 43.8 per 10000 in girls (95\% Cl 42.3 - 45.2). However, this difference was less marked as age increased. Indeed, among children under 12 months, boys had a $32.5 \%$ higher rate of hospital episodes compared to girls, whereas among children of 12 months and older, this estimate was $17.9 \%$ higher.

\section{Seasonal pattern of all-cause AGE hospital episodes}

AGE hospital episodes occurred all year-round with a major seasonal peak in spring, between March and May (epiweek 16), and a smaller increase in winter between December and January (Figs. 1 and 2).

\section{Spatial distribution of all-cause AGE hospital episodes}

In terms of spatial distribution, the three main urban districts of Portugal accounted together for more than half $(53.3 \%, 4231)$ of all the AGE hospital episodes. Lisbon was the most represented with $23.6 \%$ (1869), followed by Porto (19.4\%, 1543), and Braga (10.3\%, 819) (Table 1).

The comparison of age and sex-adjusted rates by NUTS2 suggested systematic differences between geographical units over the four-year study period (Table 2). The North and Alentejo regions presented annual rates that were higher compared to the national rate, 58.32 (95\% Cl 58.31 - 58.33) and 57.30 per 10000 children/year $(95 \% \mathrm{Cl}$ 57.28 - 57.31), respectively. On the contrary, the Algarve region and the Metropolitan Area of Lisbon (AM Lisbon) had lower rates compared to the national rate, $27.45(95 \% \mathrm{Cl}$ $27.44-27.46)$ and 37.86 per 10000 children/year $(95 \% \mathrm{Cl}$ 37.85 - 37.87), respectively.

Likewise, regions presented different dynamics over time. From 2014 to 2017, the rates of all-cause AGE hospital episodes decreased in the Algarve region and Lisbon

Table 2 - Rates (per 10000 children $<5$ years old/year) of allcause acute gastroenteritis hospital episodes by age group, sex, and NUTS2, mainland Portugal (2014 - 2017)

\begin{tabular}{lc}
\hline & $\begin{array}{c}\text { Rates }(95 \% \mathrm{Cl}) \\
(/ 10000 \text { children }<5 \text { years old/year })\end{array}$ \\
\hline Overall & $48.0(46.9-49.0)$ \\
\hline Sex & \\
Girl & $43.8(42.3-45.2)$ \\
Boy & $52.0(50.5-53.5)$ \\
Age groups (in months) & \\
$<12$ & $95.1(91.8-98.5)$ \\
$12-23$ & $71.4(68.5-74.3)$ \\
$24-35$ & $37.1(35.0-39.2)$ \\
$36-47$ & $22.7(21.1-24.3)$ \\
$48+$ & $17.0(15.6-18.3)$ \\
NUTS2* & \\
Norte & $58.32(58.31-58.33)$ \\
Centre & $47.05(47.04-47.06)$ \\
Alentejo & $57.30(57.28-57.31)$ \\
Lisbon Metropolitan Area & $37.86(37.85-37.87)$ \\
Algarve & $27.45(27.44-27.46)$ \\
\hline *age-sex adjusted rates &
\end{tabular}




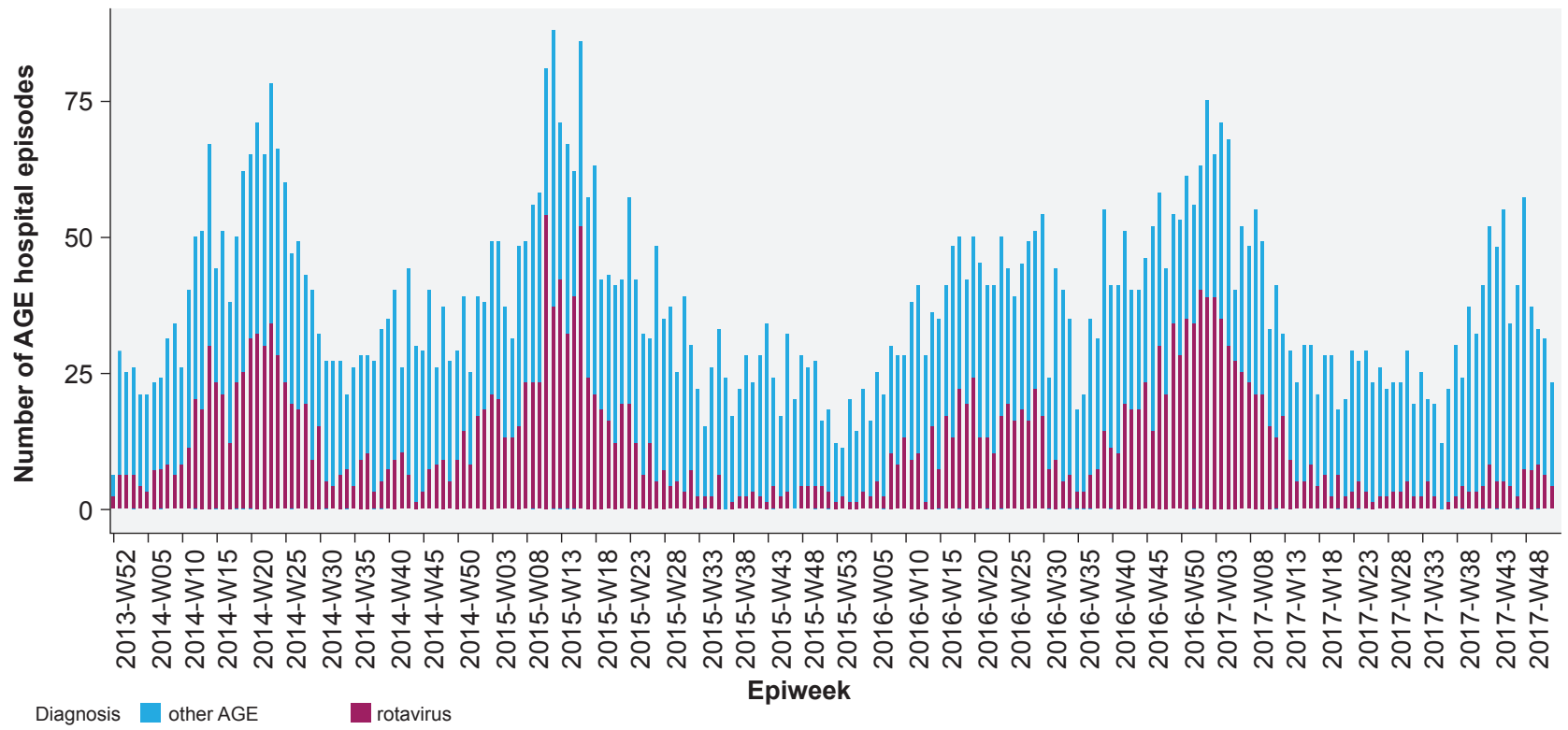

Figure 1 - Weekly number of rotavirus and all-cause acute gastroenteritis hospital episodes in children $<5$ years old, mainland Portugal (2014 - 2017)

AGE: all-cause acute gastroenteritis

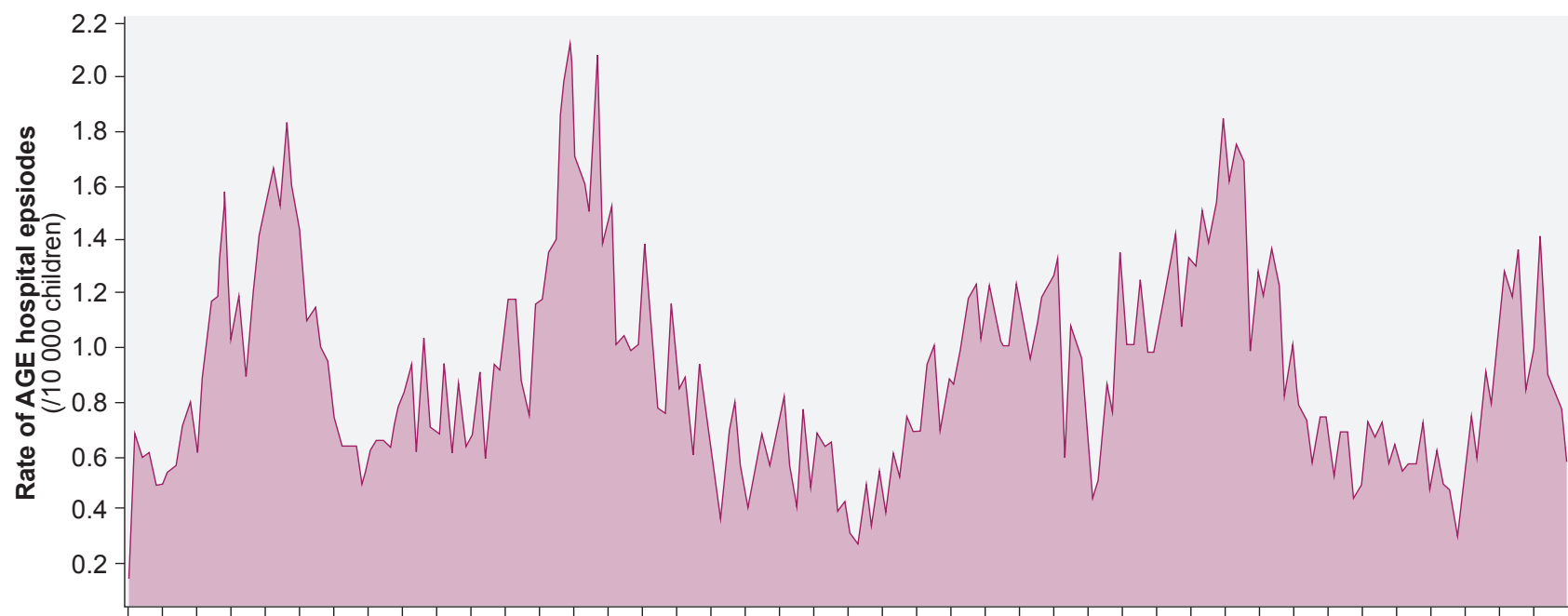

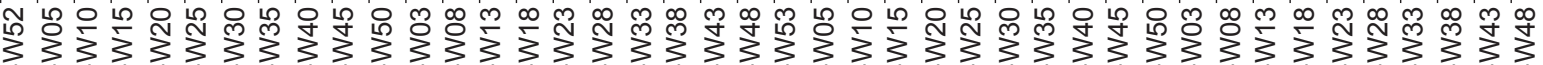

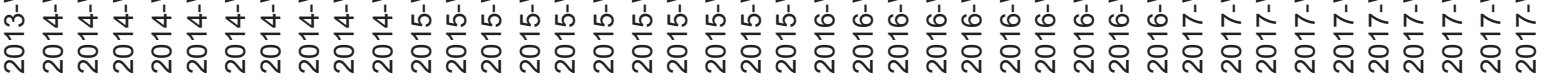

\section{Epiweek}

Figure 2 - Weekly rate of rotavirus and all-cause acute gastroenteritis hospital episodes in children $<5$ years old, mainland Portugal (2014 - 2017)

AGE: all-cause acute gastroenteritis

Metropolitan Area, from 36.05 (95\% Cl 36.04 - 36.07) in 2014 to 22.58 per 10000 children/year $(95 \%$ Cl 22.57 22.59 ) in 2017 for Algarve, and from 39.20 (95\% Cl 39.19 - 39.22) in 2014 to 30.18 per 10000 children/year $(95 \% \mathrm{Cl}$ 30.16 - 30.19) in 2017 for Lisbon Metropolitan Area. However, in the North region, the rate continuously increased during the four-year study period, from 53.92 (95\% Cl 53.90 - 53.94) in 2014 to 64.09 per 10000 children/year $(95 \% \mathrm{Cl}$ 64.06 - 64.11) in 2017. Finally, in the Centre and Alentejo regions, the rates first increased until 2016, before a marked decrease in 2017 (Fig. 3).

\section{DISCUSSION}

In this study, we described the burden and trends of severe rotavirus infections and all-cause AGE hospital episodes in children under five years old in mainland Portugal, between 2014 and 2017. To the best of our knowledge, this is the first study providing nationwide analysis of such data in Portugal.

Our main findings are that, on average, there were 1985 hospital episodes of all-cause AGE per year among children under five years old in mainland Portugal during the study period. The average annual rate of all-cause AGE hospital 


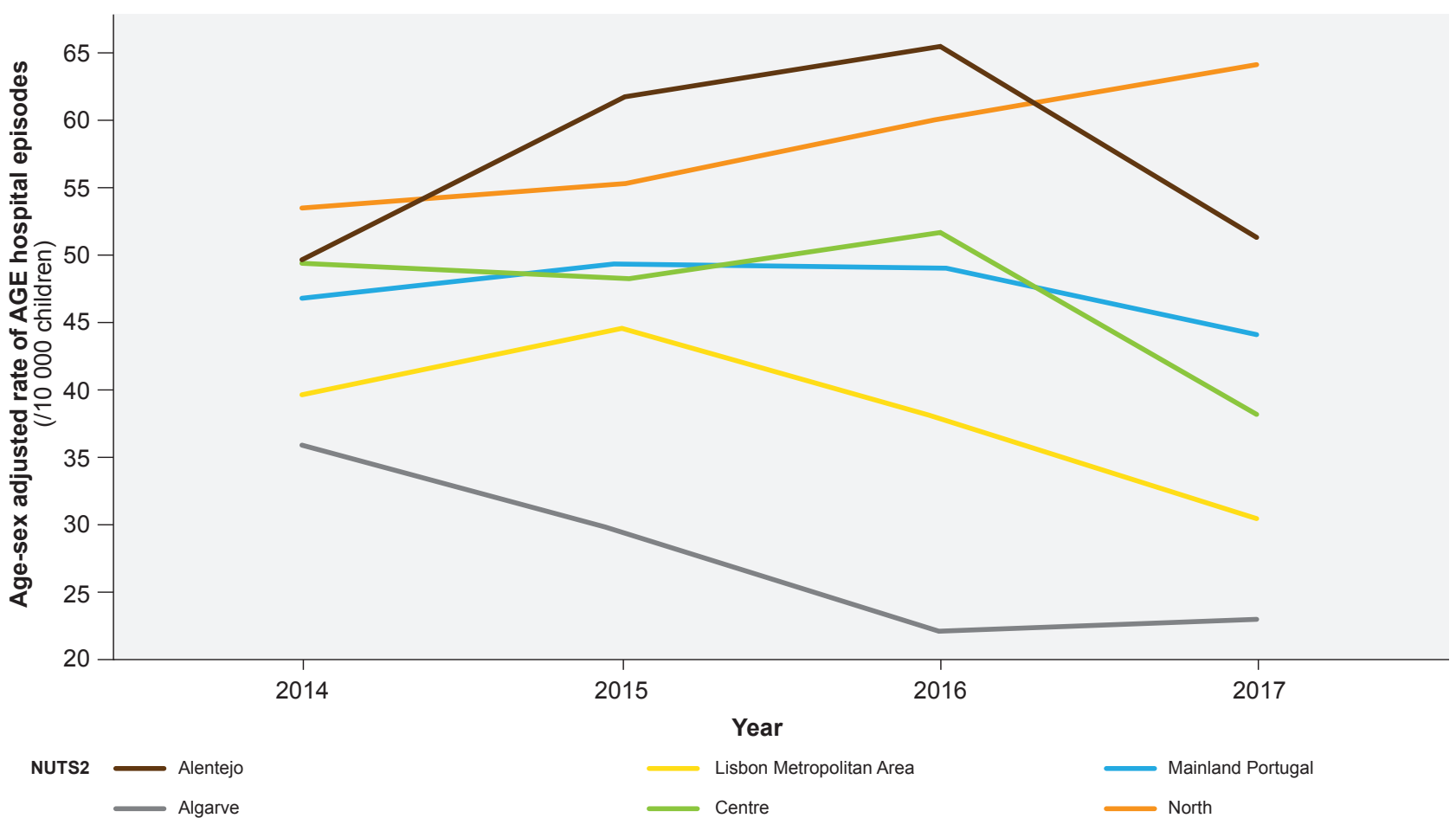

Figure 3 -Annual age-sex-adjusted rates of rotavirus and all-cause acute gastroenteritis hospital episodes by NUTS2 (per 10000 children $<5$ years old), mainland Portugal (2014 - 2017)

AGE: all-cause acute gastroenteritis

episodes was 48.0 per 10000 children under five years old, such that 1 in 208 children was likely to attend hospital for all-cause AGE by the age of five. Furthermore, $67.8 \%$ of those episodes occurred in children under 24 months old, and $57.3 \%$ in the first year of life. All-cause AGE hospital episodes presented a clear seasonality with a major peak in early spring, around March to May, and a smaller winter peak around December/January.

Our findings were consistent with the current knowledge on all-cause AGE and rotavirus epidemiology in Portugal and in Europe. First, the national rate in Portugal falls within the range of national estimates for European countries, i.e. $30-60$ per 10000 children under five..$^{2,23}$ Secondly, younger age groups have been consistently found at higher risk of hospital admission for all-cause AGE in the literature. ${ }^{28}$ Specifically, the highest incidence of rotavirus is generally reported in children between six and 24 months, as younger infants are thought to be protected by maternal antibodies, ${ }^{29}$ although a higher incidence in very young children in some other contexts has been noted. ${ }^{30}$ Moreover, the seasonality concurs with previous observations in Portuga| ${ }^{20}$ and Europe. ${ }^{2}$ Finally, mortality due to AGE in children is known to be very low in high-income countries, and Portuguese data did not contradict this. ${ }^{10,13}$

We also found spatial disparities between geographical units at the NUTS2 level. In fact, despite secular trends, all-cause AGE are known to vary widely in location and time with both demographic and environmental factors. ${ }^{31}$ Nevertheless, spatial disparities between NUTS2 should also be interpreted with caution, as they are likely to reflect differ- ences in healthcare-seeking behaviour, access to primary care and hospitals, hospital productivity, local hospital clinical guidelines for the management of acute gastroenteritis, and capacities and delays in coding of hospital episodes. Alternatively, these disparities might be further investigated in the light of differences in rotavirus vaccine coverage, and possibly, in the different strains in circulation. ${ }^{32,33}$

Because this study focuses on hospital morbidity, it primarily reflects rotavirus infections and severe acute gastroenteritis that require hospital attendance. Various studies suggest that the burden of all-cause AGE at the primary care level and the household level (i.e., home-based care) is much higher. According to the ECDC, ${ }^{2}$ two to four times more children than those hospitalized are estimated to seek medical care in outpatient settings. Other studies estimated that for each child hospitalized with rotavirus infection, five to ten children require a primary care visit, and for each child requiring medical care, three to five symptomatic children would receive home-based care. ${ }^{1,34-36}$ In Portugal, the healthcare system provides universal health coverage and is organized in a pyramidal structure in which primary health care centres are the first point of contact for individuals seeking care. Thus, it seems reasonable to extrapolate the burden of all-cause AGE at the primary care and household levels from our findings about the hospital episodes burden, as suggested by the literature. Additional studies would be needed to further analyse the burden of all-cause AGE from primary care records.

Our study has some limitations. The hospital morbidity database is subject to delays in the coding of hospital 
episodes, which could lead to an under-estimation in the number of hospital episodes. We expect this to have a very limited impact, because the database used in this study was published in 2019, i.e. two years after the end of the study period. Additionally, the database only refers to public hospitals. Nonetheless, the NHS provides universal coverage while the private sector tends to offer complementary services. Only a small proportion (10\%) of the population benefits from private insurance coverage, ${ }^{37}$ and most institutions with emergency paediatric departments belong to the NHS. ${ }^{38}$ Moreover, minor misclassifications of diagnoses could have occurred at the hospital level with the shift from the $9^{\text {th }}$ to the $10^{\text {th }}$ Edition of the ICD-CM classification, in 2017. We limited further impact on the data by systematically referring to concordance tables between the two versions.

Furthermore, it is worth highlighting that this study did not investigate the factors associated with hospital attendance. For instance, it was not possible to link the anonymised hospital records with vaccination records of the individuals. Further studies should be conducted to assess the relevance of risk factors for severe cases of AGE requiring hospital attendance to the Portuguese context, as described in the literature (e.g., premature birth, low birth weight). ${ }^{39}$

\section{CONCLUSION}

Our study provides the first national analysis of the burden and trends of severe rotavirus infections and all-cause AGE hospital episodes in children under five years old in mainland Portugal, before the introduction of the rotavirus vaccine in the National Immunization Programme.

We showed that, during the study period, rotavirus and all-cause AGE represented 1985 hospital episodes/year, 7306 days of hospital attendance/year, and an average rate

\section{REFERENCES}

1. Parashar UD, Hummelman EG, Bresee JS, Miller MA, Glass RI. Global illness and deaths caused by rotavirus disease in children. Emerg Infect Dis. 2003;9:565-72.

2. European Centre for Disease Prevention and Control. ECDC Expert opinion on rotavirus vaccination in infancy. Stockholm: ECDC; 2017.

3. Giaquinto C, Van Damme P, Huet F, Gothefors L, Van der Wielen M. Costs of community-acquired pediatric rotavirus gastroenteritis in 7 european countries: The Reveal Study. J Infect Dis. 2007;195:36-44.

4. Soriano-Gabarró M, Mrukowicz J, Vesikari T, Verstraeten T. Burden of rotavirus disease in European Union countries. Pediatr Infect Dis J. 2006;25:7-11.

5. Pediatric ROTavirus European CommitTee (PROTECT). The paediatric burden of rotavirus disease in Europe. Epidemiol Infect. 2006;134:90816.

6. World Health Organization. Immunization, vaccines, and biologicals: rotavirus. Geneva: WHO. [accessed 2019 Oct 28]. Available from: http:// www.who.int/immunization/diseases/rotavirus/en.

7. World Health Organization. WHO recommends use of rotavirus vaccines in all national immunization programmes. Geneva: WHO. [accessed 2019 Oct 22]. Available from: https://www.who.int/immunization/ newsroom/newsstory_rotavirus_vaccines_immunization_programmes/ en/.

8. European Center for Disease Control. Vaccine scheduler. Stockholm: ECDC. [accessed 2020 Feb 24]. Available from: https://vaccineschedule.ecdc.europa.eu/Scheduler/ByDisease?SelectedDiseaseld=3 2\&SelectedCountryldByDisease $=-1$. of 48.0 hospital episodes per 10000 children under five years old, with episodes occurring all year-round despite a seasonal pattern. Our results suggest that severe rotavirus infections and acute gastroenteritis hospital episodes still represent an important health and economic burden in children under five years old.

In the future, monitoring these trends in relation with rotavirus vaccine coverage could be useful to assess the impact of the vaccination programme on the change in hospital attendance and associated costs..$^{22,25}$

\section{AUTHORS CONTRIBUTION}

HL: Conception of the study, data acquisition and processing, draft of the manuscript.

RSM: Conception and supervision of the study, critical review of the manuscript.

\section{PROTECTION OF HUMANS AND ANIMALS}

The authors declare that the procedures were followed according to the regulations established by the Clinical Research and Ethics Committee and to the Helsinki Declaration of the World Medical Association, updated in 2013.

\section{DATA CONFIDENTIALITY}

The authors declare having followed the protocols in use at their working center regarding patients' data publication.

\section{COMPETING INTERESTS}

The authors have declared that no competing interests exist.

\section{FUNDING SOURCES}

None.

9. The Rotavirus Organization of Technical Allies (ROTA). Rotavirus vaccine introduction and coverage. ROTA Council. [accessed 2020 Feb 24]. Available from: https://rotacouncil.org/vaccine-introduction/globalintroduction-status/.

10. Aliabadi N, Antoni S, Mwenda JM, Weldegebriel G, Biey JNM, Cheikh $D$, et al. Global impact of rotavirus vaccine introduction on rotavirus hospitalisations among children under 5 years of age, 2008-16: findings from the Global Rotavirus Surveillance Network. Lancet Glob Health. 2019;7:893-903.

11. Karafillakis E, Hassounah S, Atchison C. Effectiveness and impact of rotavirus vaccines in Europe, 2006-2014. Vaccine. 2015;33:2097-107.

12. Poelaert D, Pereira P, Gardner R, Standaert B, Benninghoff B. A review of recommendations for rotavirus vaccination in Europe: arguments for change. Vaccine. 2018;36:2243-53.

13. Troeger C, Khalil IA, Rao PC, Cao S, Blacker BF, Ahmed T, et al. Rotavirus vaccination and the global burden of rotavirus diarrhea among children younger than 5 Years. JAMA Pediatr. 2018;172:958-65.

14. Marlow R, Ferreira M, Cordeiro E, Trotter C, Januário L, Finn A, et al. Case control study of rotavirus vaccine effectiveness in Portugal during 6 years of private market use. Pediatr Infect Dis J. 2015;34:509-12.

15. Parez N, Giaquinto C, Du Roure C, Martinon-Torres F, Spoulou V, Van Damme $\mathrm{P}$, et al. Rotavirus vaccination in Europe: drivers and barriers. Lancet Infect Dis. 2014;14:416-25.

16. Comissão de Vacinas da Sociedade de Infeciologia Pediátrica e da Sociedade Portuguesa de Pediatria. Recomendações sobre vacinas extra programa nacional de vacinação - Atualização 2018. Vacina 
contra rotavírus. Lisboa: SIP-SPP; 2018.

17. Portugal. Despacho n. ${ }^{\circ} 12434 / 2019$. Diário da República, II Série, n. ${ }^{\circ}$ $250(2019 / 12 / 30)$. p.30-31.

18. Rodrigues F, Alves MC, Alves AF, Lemos L. Etiologia das gastroenterites agudas em unidade de internamento de curta duração: estudo prospectivo de 12 meses. Acta Pediatr Port. 2007;38:13-7.

19. Escobar C, Silva T, Costa B, Oliveira M, Correia P, Ferreira GC, et al. Gastroenterite aguda em crianças internadas na área de Lisboa. Port J Pediatr. 2013;44:148-55.

20. Rodrigues F, Lopes Al, Iturriza-Gomara M, Nawaz S, Cruz A, Antunes $\mathrm{H}$, et al. Gastroenterite aguda por rotavírus em Portugal: estudo multicêntrico. Acta Pediatr Port. 2015;46:219-25.

21. Rodrigues F, Iturriza-Gómara M, Marlow R, Gray J, Nawaz S, Januário $\mathrm{L}$, et al. The evolving epidemiology of rotavirus gastroenteritis in central Portugal with modest vaccine coverage. J Clin Virol. 2013;56:129-34.

22. World Health Organization. Generic protocol for monitoring impact of rotavirus vaccination on gastroenteritis disease burden and viral strains. Geneva: WHO; 2008. [accessed 2020 Feb 04]. Available from: https:// apps.who.int/iris/handle/10665/69913.

23. Van Damme P, Giaquinto C, Huet F, Gothefors L, Maxwell M, Van der Wielen M. Multicenter prospective study of the burden of rotavirus acute gastroenteritis in Europe, 2004-2005: The Reveal Study. J Infect Dis. 2007;195:4-16.

24. World Health Organization. International classification of diseases. Geneva: WHO. [accessed 2020 Jul 10]. Available from: http://www.who. int/classifications/icd/en/.

25. European Centre for Disease Prevention and Control. Impact of rotavirus vaccination - Generic study protocol. Stockholm: ECDC; 2013.

26. Instituto Nacional de Estatística. População residente $\left(\mathrm{N} .^{\circ}\right)$ por local de residência (NUTS - 2013), sexo e grupo etário; Anual. Lisboa. [accessed 2021 Mar 01]. Available from: www.ine.pt/xportal/ xmain?xpid=INE\&xpgid=ine_indicadores\&indOcorrCod=0008273\&xlan $\mathrm{g}=\mathrm{pt}$.

27. R Core Team. R: a language and environment for statistical computing. Vienna: R Foundation for Statistical Computing. [accessed 2020 Feb 04]. Available from: https://www.R-project.org/.

28. Hasso-Agopsowicz M, Ladva CN, Lopman B, Sanderson C, Cohen AL, Tate JE, et al. Global review of the age distribution of rotavirus disease in children aged $<5$ years before the introduction of rotavirus vaccination.
Clin Infect Dis. 2019;69:1071-8.

29. Long SS, Prober CG, Fischer M. Principles and practice of pediatric infectious diseases. $5^{\text {th }}$ ed. Philadelphia: Elsevier Health Sciences; 2017.

30. Sanderson C, Clark A, Taylor D, Bolanos B. Global review of rotavirus morbidity and mortality data by age and region. Geneva: WHO; 2011. [accessed 2020 Jul 15]. Available from: https://www.who.int/ immunization/sage/meetings/2012/april/Sanderson_et_al_SAGE_ April_rotavirus.pdf.

31. Pitzer VE, Viboud C, Simonsen L, Steiner C, Panozzo CA, Alonso WJ, et al. Demographic variability, vaccination, and the spatiotemporal dynamics of rotavirus epidemics. Science. 2009;325:290-4.

32. Antunes H, Afonso A, Iturriza M, Martinho I, Ribeiro C, Rocha S, et al. $\mathrm{G} 2 \mathrm{P}[4]$ the most prevalent rotavirus genotype in 2007 winter season in an European non-vaccinated population. J Clin Virol. 2009;45:76-8.

33. Rodrigues F, Iturriza M, Gray J, Januário L, Lemos L. Epidemiology of rotavirus in Portugal: G9 as a major cause of diarrhoea in nonhospitalised children. J Clin Virol. 2007;40:214-7.

34. Vesikari T, Rautanen $\mathrm{T}$, Von Bonsdorff $\mathrm{CH}$. Rotavirus gastroenteritis in Finland: burden of disease and epidemiological features. Acta Paediatr. 1999;88:24-30.

35. Ford-Jones EL, Wang E, Petric M, Corey P, Moineddin R, Fearon M. Rotavirus-associated diarrhea in outpatient settings and child care centers. The Greater Toronto Area/Peel Region PRESI Study Group. Pediatric Rotavirus Epidemiology Study for Immunization. Arch Pediatr Adolesc Med. 2000;154:586-93.

36. Rodriguez WJ, Kim HW, Brandt CD, Schwartz RH, Gardner MK, Jeffries $B$, et al. Longitudinal study of rotavirus infection and gastroenteritis in families served by a pediatric medical practice: clinical and epidemiologic observations. Pediatr Infect Dis J. 1987;6:170-6.

37. Nunes AM, Ferreira DC. Reforms in the Portuguese health care sector: challenges and proposals. Int J Health Plann Manage. 2019;34:21-3.

38. Entidade Regulatora da Saúde. Caracterização do acesso dos utentes a cuidados de saude infentil e juvenil de pediatria. Lisboa: ERS; 2011. [Accessed 2020 Jul 17]. Available from: https://apch2.ers.pt/ pages/73?news_id=95.

39. Huppertz HI, Salman N, Giaquinto C. Risk factors for severe rotavirus gastroenteritis. Pediatr Infect Dis J. 2008;27:11-19. 